\title{
Constraints to Budget Implimentation in Nigeria
}

\author{
Nafisatu Kazeem, Nuhu James Bwala, Shizar Yusuf Dunga
}

\begin{abstract}
The stories of disparity between budget and its implementation in Nigerian public sector are replete in newspapers, public discourses and academic journals. Reasons advanced for this include: corruption, fluctuating oil revenue, unstable economic parameters and poor budget monitoring. The main objective of this paper was to examine the constraints to budget implementation. Relevant literature review gave the research the conceptual frame work desired for the exercise. Data were collected through questionnaires and other secondary data source. Chi-square was used in testing the hypotheses. Three hypotheses were set forth and tested using two ministries namely: education and finance in Bauchi State of Nigeria. Thirty high ranking staff involved in budget preparation and implementation out of thirty-five administered with questionnaires responded to time. Using the students t-test, the first hypothesis (There is no significant relationship between corruption and budget implementation ) it was discovered with t-cal. (3.41) greater than t-tab (1.679) corruption always hinder budget implementation. The second hypothesis (ministries have no adequate measures to address budget variances), with $t$-cal. (3.497) greater than t-tab (1.699), the two ministries do not adequately monitor budget so as to achieve the expected goal. It can be concluded that reasons for budget implementation constraints can be explained outside those factors. The paper concludes by making recommendations to solve implementation constraints in government departments.
\end{abstract}

Index Terms - Budget, Budget implementation, Limiting factor to budget implementation.

\section{INTRODUCTION}

\section{A. Background to the Study}

It has been observed that poor and unrealistic policy implementation has long been the bane of socio-economic development in the developing countries and by implication, Nigeria. Budget implementation is not simply a matter of executing the approved budget. In almost every country, the implemented budget varies from the adopted one which is brought about by the country's fiscal conditions, stability and certainty in the country's finances, the role of the finance ministry, and the type of budget system. A highly itemized budget may experience more variance than one which gives managers spending discretion. The trend in contemporary public management is to give spending units more flexibility in implementing their budgets, even though this may not be appropriate in countries with inadequate management controls

Nafisatu Kaseem, student of accounting in Abubakar Tafawa Balewa University Bauchi.

Nuhu James Bwala, student of accounting in Abubakar Tafawa Balewa University Bauchi.

Shizar Yusuf Dung, student of accounting in Abubakar Tafawa Balewa University Bauchi.
Samuel and Wilfred (2009) defined budget as a comprehensive document that outlines what economic and non-economic activities a government wants to undertake with special focus on policies, objectives and strategies for accomplishment that are substantiated with revenue and expenditure projections.

Ogujiuba and Ehigiamusoe (2013) stated that the national budget is the most important economic policy instrument for a government and it reflects the government's priorities regarding social and economic policy more than any other document. In addition, the instrument translates policies, campaign promises, political commitments, and goals into decisions regarding where funds should be spent and how funds should be collected. The focus on the budget has assumed greater prominence in recent years with increasing democratization, civil society participation and the desire to respond to development challenge of poverty. The national budget is basically divided into more current and capital budget.

It is necessitated by the limitedness or scarcity of revenue which have alternative uses. In business organization, their primary goals or objectives center well on liquidity, profitability and contribution on the economic and social improvement. In the same way non-business organizations such as federal, state and local governments have their specific objective which are also economic and non-economic in nature.

The invaluable role of the state government with the attendant development nearer to the people has become a relevant discourse of our time. Development is a matter of inner emotion. It integrates the people into the plans and policies of government.

A major and justifiable area of development discourse concerns the appropriate instrument of implementation. In Nigeria, state government has historically provided services of importance to its citizens in rural and urban area which includes provision of basic services like water, roads, health facilities, education. Of late, the role of state government in providing these services has attracted public concern. Furthermore, it has generated national crisis as a result of increasing rate of poverty among the rural people. Some scholars view this development to poor budgeting and implementation while others associate it to the federal government interference. Whatever may be the reason, there is considerable emphasis, possibly on over-emphasis on budgeting in the federal government against the under emphasis on budgeting practices and procedures in state and local government in Nigeria. 


\section{STATEMENT OF THE PROBLEM}

Why has the national budgetary process in the Nigerian nation continued to witness procedural indiscipline and crises of implementation? According to Olaoye (2014, p.39) therefore, the Nigeria Federal budget has been facing a myriad of challenges dispossessing it of the powers to achieve its expected goals. We immediately opine that the national budget has not lived up to expectation (on annual bases) because the embedded processes have been abandoned to the whims and caprices of bureaucrats and politicians. Public sector budgeting is a systematic activity. And it is this systematic nature of the budget that makes it a central instrument of public sector financial administration (Ekhator \& Chima, 2015, p.3). In this system, the critical issues are to actually originate from the concerns and welfare of the people (the tax payers) and the results of the processes entailed by the system are also subject to the approval of the people.

Hence, a national budget is not an annual ritual of governance and it must also be initiated, articulated, implemented and evaluated with minimal partisan political considerations. According to Ekeocha (2012) in Sam-Tsokwa and Ngara (2016, p.5), the ability to make timely and sensible fiscal choices is one of the hallmarks of good governance. It seems however, as if this ability is deficient in the public sector budgetary processes in Nigeria. According to Igbara, Tordee, Nwadike and Abuba (2016. p.2), another important purpose of a public-sector budget is public accountability, which is accomplished by a system of internal checks based on record-keeping. The budgetary system thus facilitates accountability by public officials of the public funds entrusted to them. Coordination is also provided by the budget to reconcile the various services and programmes competing for funds (Igbara, Tordee, Nwadike \& Abuba, 2016. p.3). The continuing cases of monumental sleaze in the Nigerian public sector are accordingly attributable to a failure of the national budgetary mechanisms.

Furthermore, the national budget in Nigeria is annually characterized by an avoidable executive-legislature tangle. In the viewpoints of Igboeche $(2017$, p.60) a national budget is the financial statement of the government's proposed expenditure and expected revenue during a particular period of time, usually a year. Such budgets are usually employed to attain the objectives of full employment in the economy, price stability, rising growth in national outputs, balance of payments equilibrium and equity in income distribution. In the Nigerian system however, the national budget is more generically known for its legislature-executive face-offs. Expenditure could be incurred outside budgetary provisions and revenues may also be banked and applicable funds subsequently utilized as the public servants consider appropriate.

To attain the ideal budgetary objectives, Igboeche (2017, p.60) continued, the budget must be seen as exhibiting certain features. It is a financial plan of operation, it is for a fixed period, it must be an authorization to collect revenue and incur expenditure and it must be objective. Hence, Igboeche further posited that budgeting is without doubt the commonest and most popular technique for controlling expenditure within government business. It provides a basis for appraising government, ministries, departments and agencies' performances and forces government to think hard about their resource needs. But contrary to the foregoing ideal tendencies, the Nigerian budget has become a theoretical plan of operation, never strictly for a fixed period; it must not be an authorization but only a guide whose provisions could be side-lined without consequences. It could be treated as a subjective issue on which different officials present conflicting trajectories of interpretation depending on their connections within the political-administrative set up.

\section{OBJECTIVES}

The main purpose of this study is to examine the constraints to budget implementation in Nigeria. To achieve this objective, the following objectives will be considered

1. To examine how corruption affect budget implementation.

2. To assess the effect of monitoring on effectiveness of budget implementation

3. To examine inadequate finance on budget implementation.

\section{RESEARCH QUESTIONS}

The following research questions were raised for this study.

1. To what extend does corruption affects budget implementation?

2. To what extend does budget monitoring affects budget implementation?

3. To what extend does inadequate finance affects budget implementation?

\section{RESEARCH HYPOTHESES}

The following hypotheses were formulated

1. There is no significant relationship between corruption and budget implementation.

2. There is no significant relationship between budget monitoring and budget implementation.

3. There is no significant relationship between inadequate of finance and budget implementation.

\section{SIGNIFICANCE OF THE STUDY}

The result of the study will be useful source of information particularly to Nigerian government for evolving means/strategies to rigorously monitor the implementation of her budgets in order to achieve the goals.

\section{SCOPE OF THE STUDY}

The study examined the constraints to budget implementation in Nigeria. The geographical scope is limited to two ministries in Bauchi state; namely ministry of education and ministry of finance. Bauchi state is situated in the Northeast zone of Nigeria. 


\section{LITERATURE REVIEW}

Different authorities based on their views have defined budgeting proposal and constraints of its implementation. It should be noted that the concept of budgeting is as old as man himself. Just as man plans for what he needs in advance, corporate bodies, governments and institutions also plans ahead in terms of revenue and expenditure within a specific period of time.

The word "Budget" means the bag or the public purse which serve as a receptacle for the revenue and expenditure of the state (Adams,1998). Budgets evolved in two directions. At first, parliaments fought to take control of the budget and make governments accountable for the use of resources. In democratic societies for instance, approval of the budget (the power of the purse) is the main form of parliamentary control of the executive. The budget authorizes to the executive to spend and collect revenue.

Smith and Thomas (2004) defined budget as a plan for the accomplishment of programs related to objectives and goals within a definite time period including an estimate of the resources required together with an estimate of resources available usually compared with one or more past periods showing future requirements. Sullivan and Sheffrin (2003) state that a budget is derived from the French word "Budgette" which means a leather bag or a wallet. It is a statement of the financial plan of the government. It shows the income and expenditure of the government during a financial year.

Morgan (1997) opines that the budget had grown beyond a financial tools. It is above all managerial tools. It is the best tools for making sure that key resources especially performance resources are assigned to priorities and to results It is a tool that enables the managers to know when to review and revise plans either because results are different from expectation or due to environment economic contributions, market contribution or technologies changes which no longer correspond to the assumptions of the budget. Morgan emphasized that budget should be used as a tool for planning and control. According to Hudson and Andrew (1996) control involved the making of decisions based on relevant information which leads to plans and action that improve the utilization of the productive assets and services available to organization management. Effective control is said to be based or standards with which actual performance can be compared. If there are no standard then there can be no effective measure of attainment.

Budgeting as a concept of authorization explains the original purpose of budgeting as a financial plan to provide money for government institution. Consequent upon this, the government institution carries out their activities usually a year as expressed in quantitative terms ensuring effective and efficient mobilization of resources.

Ademolekun (1983) sees budget implementation as the activities that are carried out in the light of established policies. Egonmwan (1991) also says that budget implementation refers to the process of converting financial, material, technical and human inputs into outputs-goods and services. Edwards III (1980) also defines budget implementation as a stage of policy making between the establishment of a policy (such as the passage of a legislative act, the issuing of an executive order, or the promulgation of a regulatory rule) and the consequences of the policy for the people whom it affects. It also involves a wide variety of actions such as issuing and enforcing directives, disbursing funds, making loans, assigning and hiring personnel, etc.

\section{A. Empirical Review}

Ifeanyi et al. (2016) conducted a study on Nigerian budget implementation and control reforms: tools for macroeconomic growth. The aim of the study was to examine the impact of budget implementation on resource management, level of productivity, efficiency and personnel overhead costs in Nigeria. Using ex-post factor descriptive research design, questionnaires distributed to a sample of 308 were analyzed using simple percentage. The study found out that poor project conceptualization design and planning practices by ministries, department and agencies accounted for low resource management. The study recommended participatory monitoring and assessment of government project by host community members.

Olatunji et al. (2017) investigated the impact of capital budget implementation on economic growth in Nigeria. The aim of the study was to assess the impact of the implementation of capital expenditure on administrative, economic services and socio-community services on the growth of Nigerian economy. The secondary data used for the study were obtained from Central Bank of Nigeria (CBN), Statistical Bulletin. Using Augmented Dicker-Fuller unit root test, co-integration test and Error Correlation Model (ECR) for analysis, it was found that capital expenditure implementation is germane in maintaining and sustaining economic growth in Nigeria. It was recommended that government should ensure adequate implementation of capital expenditure in the country.

Innocent and Christopher (2017) did a study on budget evaluation and government performance: a study of Nigerian economy. The aim of the study was to evaluate Nigeria's federal budget and its performance. Data for the study were obtained from financial and economic reports of Nigeria. The data were analyzed both descriptively and empirically. The parameter for assessing budget credibility is the international threshold and prescribed limit for budget deficit/GDP, a minimum of $50 \%$ score performance rating for regression economic performance. The findings thereof ranks Nigeria's fiscal performance as sub-optimal but fairly satisfactory. The study recommended that budget performance should be prepared by government at the end of each year as a means of educating the citizenry of government activities.

\section{B. Limiting Factors to Budget Implementation}

Budget implementation problem occurs when the desired result on the target beneficiaries is

not actualized. Such implementation problems, however is not restricted to only the developing

nations, because the basic critical factors that are very crucial to budget implementation can be

missing in either the developed nations or the developing nations. And once that is the case, it 
invariably will lead to implementation problem(s).

According to Eze and Ani (1999) Budgeting is a great management tool. Its effectiveness

will however depend on how these limiting factors are handled in relation to the various sectional budgets and the master budgets usually when plans are being formulated, there are variation. Some of the factors responsible for these are: when the budgeted fund is inadequate to finance projects, in the area of production when the right supply of labour is not in place, lack of adequate plans capacity as well as scarce resources to carry on the budget and lack of specialization or skill on the part of the budget officers who are saddled with the responsibility of implementing budget.

Onaolapo and Olaoye (2013) stated that practical problems of budget implementation include:

1, Corruption, this is one of the set back of fruitful budgeting process. Evidences are bound in the records of Economic and Financial Crime Commission and Independent Corrupt Practices Commission. Corruption is quite endemic.

2. Fluctuating revenue and over- dependence on oil revenue.

3. Unstable economic parameters e.g. price level, unemployment e.t.c affect budgetary effectiveness.

4. Poor conception of people toward budget.

5. Unstable government policies from one fiscal year to another.

6. Inadequate finance.

7. Lack of qualified manpower.

8. Paucity of data.

9 Lack of effective budget monitoring i.e. the execution of the budget.

10. Delay in approval of project proposal by the ministry and the legislature.

\section{IMPLEMENTATION ILLUSION}

Data about the pace and magnitude of expenditure do not fully reveal how tasks are performed. Financial bias, which has been inherent in the traditional budget system was reduced somewhat with the growing emphasis on ensuring an adequate link between physical and financial progress. The need for such a link becomes even more obvious when there are excess expenditures and an inflationary environment. Excess expenditures may not always reflect cost increases and sometimes may well be the consequences of poor management. Similarly, in an inflationary situation, money expenditures may be on schedule and may frequently reflect the implementation of the directives from the central agencies that each department should absorb cost increase within allotted funds.

Budget implementation devolves different responsibilities on the central agencies whose concerns are both immediate and slightly remote. The immediate concerns are with the behaviour of the fiscal variables such as revenue, expenditure, internal and external borrowing and with the changes in the impact of these items on the economy. Major changes from expectations requires actions even during the course of the year while in some cases, action may be feasible only in subsequent years. Periodic review involves a broad oversight on the specifics of expenditures of the agencies as well as on aggregate fiscal variables.

\section{METHODOLOGY}

\section{A. Research Design}

The study area is the Bauchi State Public Service and a sample of two ministries namely: finance and ministry of education. The selected staffs of the ministries include both the junior staffs and the senior staffs. Random sampling method was used to choose the sample from the population.

Thiry-five (35) questionnaires were administered to key budgeting and finance officers in the

ministries out of which thirty (30) questionnaires were returned for analysis.

\section{DATA ANALYSIS}

\section{A. Data Analysis Techniques}

The primary data was processed using T-test at $5 \%$ level of significance to enhance the

validity and reliability of the research work.

$s=\sqrt{\frac{\Sigma(X-\Sigma X) 2}{n-1}}$

$S . E=\sqrt{\frac{S}{N-1}}$

$t=\sqrt{\frac{X-\mu 0}{\frac{S}{N}}}$

$\mu=\frac{E X P}{\sqrt{N}}$

$\mathrm{t}=$ calcualted $\mathrm{t}$ value

$\mathrm{x}=$ sample mean

$\mu=$ population mean

$\mathrm{s}=$ standard deviation of the sample

$\mathrm{n}=\mathrm{N}-1$

$\mathrm{N}=$ sample size

degree of freedom $=\mathrm{N}-1$ 
Data Analysis and Test of Hypotheses

Hypothesis 1

Effect of corruption and Budget implementation

\begin{tabular}{|c|c|c|c|c|}
\hline RESPONSE & $\begin{array}{l}\text { VALUES } \\
\text { (RANKS) }\end{array}$ & $\mathrm{X}$ & $(\mathrm{X}-\mathrm{EX} / \mathrm{N})$ & $(\mathrm{X}-\mathrm{EX} / \mathrm{N})^{2}$ \\
\hline Strongly Agree & 5 & 10 & 4 & 16 \\
\hline Agree & 4 & 8 & 2 & 4 \\
\hline Strongly Disagree & 3 & 6 & $\mathbf{0}$ & - \\
\hline Disagree & 2 & 4 & -2 & 4 \\
\hline Undecided & 1 & 2 & -4 & 16 \\
\hline Total & & 30 & & \\
\hline
\end{tabular}

$\mu=\frac{X V}{N}=\frac{(10 * 5)+(8 * 4)+(6 * 3)+(4 * 2)+(2 \cdot 1)}{30}=\frac{110}{30}=3.67$

$S=\sqrt{\frac{\sum(X-\Sigma X) 2}{n-1}}=\sqrt{\frac{40}{30-1}}=\sqrt{\frac{40}{29}}=\sqrt{1.38}=1.17$

S. $E=\sqrt{\frac{S}{N-1}}=\sqrt{\frac{1.17}{30-1}}=\sqrt{0.040}=0.20$

$t=\sqrt{\frac{X-\mu 0}{\frac{S}{N}}}=\sqrt{\frac{6-3.67}{0.20}}=3.41$

Decision Rule:

Since $t$ calculated is $>\mathrm{t}$ tabulated, i.e. $3.41>1.679$, the null hypothesis is rejected and alternate is accepted and we conclude that corruption has an adverse effect in budget implementation in ministries.

Hypothesis II

The effect of monitoring on budget implementation

\begin{tabular}{|c|c|c|c|c|}
\hline $\begin{array}{l}\text { RESPON } \\
\text { SE }\end{array}$ & $\begin{array}{l}\text { VALU } \\
\text { ES } \\
\text { S) } \\
\text { (RANK }\end{array}$ & $\mathrm{X}$ & $(\mathrm{X}-\mathrm{EX} / \mathrm{N})$ & $\begin{array}{l}(\mathrm{X}-\mathrm{EX} / \\
\mathrm{N})^{2}\end{array}$ \\
\hline $\begin{array}{l}\text { Strongly } \\
\text { Agree }\end{array}$ & 5 & $5^{1}$ & 9 & 81 \\
\hline Agree & 4 & 5 & -1 & 1 \\
\hline $\begin{array}{l}\text { Strongly } \\
\text { Disagree }\end{array}$ & 3 & 4 & -2 & 4 \\
\hline Disagree & 2 & 3 & -3 & 9 \\
\hline Undecided & 1 & 3 & -3 & 9 \\
\hline Total & & $0^{3}$ & & 104 \\
\hline
\end{tabular}

$\frac{\Sigma X}{N}=\frac{15+5+4+3+3}{5}=\frac{30}{5}=6$

$\mu=\frac{X V}{N}=\frac{(15 * 5)+(5 * 4)+(4 * 3)+(3 * 2)+(3 * 1)}{30}=\frac{86}{30}=2.87$

$S=\sqrt{\frac{\Sigma(X-\Sigma X) 2}{n-1}}=\sqrt{\frac{104}{30-1}}=\sqrt{\frac{104}{29}}=\sqrt{3.586}=1.89$

$S . E=\sqrt{\frac{S}{N-1}}=\sqrt{\frac{1.89}{30-1}}=\sqrt{0.0653}=0.256$
Reject $\mathrm{H} 0$ and accept $\mathrm{H} 1$ since t calculated is $>\mathrm{t}$ tabulated, i.e. $3.497>1.699$, therefore, we conclude that lack of budget monitoring affects budget implementation.

\section{CONCLUSION AND RECOMMENDATIONS}

\section{A. Conclusion}

From the research work carried out to determine limiting factors to budget implementation, we have found out why government budget policies go wrong at the implementation stage, especially in developing countries like Nigeria. In as much as we do not want to leave the impression that budget implementations in these countries is always a failure, the discussions was done to X-ray areas that need improvement.

Summarily, budget implementation should be reviewed periodically to ensure that programs are implemented effectively and to identify any financial or policy slip-ups, but this has not been the case with the developing countries. The review of budget implementation should cover financial, physical and other performance indicators. A comprehensive midterm review of the implementation of the budget is thus required, while the financial implementation of the budget should be reviewed monthly.

It has also been observed and concluded that most reasons for non - completion of budget are mainly internal factors which arises from the fact that most times budget rules are not programmed to affect the performance of budget.

The government from time to time should follow strictly the rules and regulation guiding

the preparation of budget in order to achieve the targeted objectives.

\section{RECOMMENDATIONS}

To bridge the gap between intention of a budget and the actual achievement of the budget

policy, consideration should also be given to the following:-

1. All the parties concerned especially the target beneficiaries should be involved at the

formulation stage to have all input accommodated. This will go a long way in providing the

needed commitment by all parties who will see the budget as originating from them.

2. Adequate information systems recording transaction at 
each stage of the expenditure cycle, and appropriate communication between the budget implementers and the target beneficiaries are also needed.

3. Once a policy is found to be useful to the people, the commitment of all concerned should be registered, to ensure that change in the administration or government will not lead to project abandonment.

4. All resources- human and material resources should be properly galvanized, and improved upon to be able to achieve a problem free implementation.

\section{APPENDIX}

Questionnaire

Section B: Research Questions

\begin{tabular}{|c|c|c|c|c|c|c|}
\hline $\mathbf{S} / \mathbf{N}$ & & $\begin{array}{l}\text { Strongly } \\
\text { Agree }\end{array}$ & Agree & Undecided & Disagree & $\begin{array}{l}\text { Strongly } \\
\text { disagree }\end{array}$ \\
\hline 1 & $\begin{array}{l}\text { Budget is a comprehensive document that } \\
\text { outlines what economic and non-economic } \\
\text { activities a government wants to undertake with } \\
\text { special focus on policies, objectives and strategies } \\
\text { for accomplishment that are substantiated with } \\
\text { revenue and expenditure projections. }\end{array}$ & & & & & \\
\hline 2 & $\begin{array}{l}\text { Budget implementation is the activities that are } \\
\text { carried out in the light of established policies. }\end{array}$ & & & & & \\
\hline 3 & $\begin{array}{l}\text { Nigeria Federal budget has been facing a } \\
\text { myriad of challenges dispossessing it of the } \\
\text { powers to achieve its expected goals. }\end{array}$ & & & & & \\
\hline 4 & $\begin{array}{l}\text { Corruption is one of the challenges we are } \\
\text { facing that affects budget implementation. }\end{array}$ & & & & & \\
\hline 5 & $\begin{array}{l}\text { Inadequate finance affects carrying out } \\
\text { expected project as planned. }\end{array}$ & & & & & \\
\hline 5 & $\begin{array}{l}\text { Lack of effective budget monitoring is the } \\
\text { cause of failure in budget implementation }\end{array}$ & & & & & \\
\hline 6 & $\begin{array}{l}\text { Unstable government policies from one fiscal } \\
\text { year to another affects the implementation of } \\
\text { budget. }\end{array}$ & & & & & \\
\hline
\end{tabular}

\section{REFERENCES}

[1] Adam, Carter .H. (1998): The Science of Finance, Henry Holt and Co, New York.

[2] Ademolekun, Ladipo (1983). Public administration-A Nigerian and comparative perspective; New York: Longman

[3] Edwards III, George C.(1980). Implementing public policy; Washington: Congressional Quarterly Press.

[4] Egonmwan, J.A. (1991). Public policy analysis-Concepts and applications; Benin City: S.M.O. Aka and Brothers Press.

\section{Section A: Personal Data}

Please tick (x) in the most appropriate option from the list of options that followed each question

1. Please indicate your gender: Male ( ) or Female ( )

2. Please indicate your age: $20-30$ years( ) 31-40( ) 4150( ) above 50( )

3 . Please indicate your working experience :0-5 years( ) 6-10 years( ) 11- 15 years( ) above 15 years( )

4. Please indicate your education background: $\operatorname{HND}($ ) B.Sc( ) MBA/MSc( ) others( )

5. P lease indicate your position in the ministry: Junior staff( ) senior staff( ) Manager( )

6. Please indicate your marital status: single( ) Married( ) Divorced( ) Widowed( )
[5] Ekeocha, P. C. (2012). An analysis of the federal budgeting process in Nigeria: Implications for institutional reforms for achieving timeliness. Developing Country Studies, 2(6), 64-77.

[6] Ekhator, V.E \& Chima, P. (2015). Budget and implementation of public policy in Nigeria. British Journal of Economics, Management \& Trade, 10(3): 1-8.

[7] Eze and Ani (1999). Management Accounting, Machraw- Hill, New York.

[8] Ifeanyichuku, A. O., Ezeamama, N.C., Joy, N. U. \& Mgbodile, C.C. (2016). Budget implementation and control reforms: tool for macroeconomic growth. British Journal of Economics, Management and Trade 11(2), 1-13. 
[9] Igbara, F. N., Tordee, B., Nwadike, G., \& Abuba, S. (2016). Budget and budgeting in the third tier of Government: Problems and prospects. Equatorial Journal of Finance and Management Sciences, 1(1), 1-9.

[10] Igboeche, P.O.I. (2017). National budgets and budgeting in Nigeria: A critical analysis of 2016 budget. International Journal of Research in Arts and Social Sciences, 9(2), 50-61.

[11] Innocent, N. \& Christopher, E. (2017). Budget evaluation and government performance: a case of the Nigeria economy. Journal of Economics, Management and Trade 20(1), 28-30.

[12] Morgan, J.S. (1997). The Managerial Imperative of Evaluating Non Capital.

[13] Ogujiuba, K. K. \& Ehigiamusoe, K. (2013). Capital budget Implementation in Nigeria: Evidence from the 2012 Capital Budget, 24(10), 299-314.

[14] Olatunji, O. C., Oladipupo, O. F. \& Joshua, A. A. (2017). Impact of capital budget implementation on economic growth in Nigeria Archives of Business Research 5(10), 89-102.

[15] Omolehinwa Eddy (1989): "Public Budgeting and Finance", Vol. 9.

[16] Onaolapo, A.R. \& Olaoye, F.O.(2013).Appraisal of the factors contributing disparity in budget proposal and implementation. Arabian Journal of Business and Management Review (OMAN Chapter) Vol. 2, No.11; June 2013

[17] Samuel, C.U. \& Wilfred, I.U. (2009). Problems and Prospects of Budgeting and Budget Implementation in Local Government in Nigeria. African Journal of Business Management Vol.3(12).

[18] Sullivan, A. \& Sheffrin, S. M. (2003). Economics Principles in Action. Pearson Prentice Hall, New Jersey. p. 502.

Nafisatu Kaseem is a student of accounting in Abubakar Tafawa Balewa University Bauchi.

Nuhu James Bwala is a student of accounting in Abubakar Tafawa Balewa University Bauchi.

Shizar Yusuf Dung is a student of accounting in Abubakar Tafawa Balewa University Bauchi. 